\title{
PENILAIAN PENGENDALIAN BIAYA DAN WAKTU PADA PROYEK PENINGKATAN JALAN MENGGUNAKAN METODE EARNED VALUE
}

\author{
Bakhtiar. A \\ Jurusan Teknik Sipil Politeknik Negeri Lhokseumawe \\ Jl. Banda Aceh-Medan, Km.280 Buket rata \\ Email: bakhtiar_aw@yahoo.co.id
}

DOI: http://dx.doi.org/10.29103/tj.v8i2.172

\begin{abstract}
Abstrak
Tujuan penelitian ini adalah untuk mengevaluasi jumlah biaya dan penggunaan waktu yang telah digunakan pada proyek Peningkatan Jalan. Metode yang digunakan dalam penelitian ini berupa konsep nilai hasil (earned value analysis) mengkaji kecenderungan varian jadwal dan varian biaya pada suatu periode selama proyek berlangsung. Dengan melakukan studi dengan earned value ini dilakukan evaluasi penyelesaian proyek dengan BCWP sebesar Rp. 864,310,464.06, BCWS sebesar Rp. 393,436,638.08, dan ACWP sebesar Rp. 591,235,630.69, Ditinjau dari varian biaya $(\mathrm{CV})>0$ dengan Indeks kinerja biaya $(\mathrm{CPI})>1$ sehingga diperoleh biaya penyelesaian proyek (EAC) sebesar 68\% dari anggaran rencana yaitu sebesar Rp. 2,037,182,494.70, Sedangkan dari aspek jadwal proyek mengalami pengurangan waktu sebesar $47 \%$ atau dari rencana 16 minggu menjadi 9,45 minggu sebagaimana ditunjukkan nilai SPI $>1$.
\end{abstract}

Kata kunci: Biaya, schedule, kinerja, earned value, varians.

\begin{abstract}
The purpose of this study is to evaluate the amount of cost and use of time that has been used in the Improvement Project Street. The method that used in this study is concept of yield value (earned value analysis) review trends in schedule variants and cost variants for a period during the project. By doing this earned value study method, evaluating the completion of the project with BPWP as Rp. 864.310.464,06, BCWS as Rp. 393.436.638,08, and ACWP as Rp. 591.235.630,69, in terms of cost variant (CV) $>0$ with cost performance index (CPI) $>1$ so that is obtained project completion cost (EAC) $68 \%$ of budget plan that is Rp. 2.037.182.494,70, while from the schedule aspects the project has decreased in time by $47 \%$ of plan or 16 weeks to be 9,45 weeks indicated value SPI $>1$.
\end{abstract}

Keywords: cost, schedule, performance, earned value, variant

\section{Latar Belakang}

Untuk dapat menentukan keberhasilan proyek, maka dari itu diperlukan adanya penjadwalan dan pengendalian biaya yang baik pada penelitian ini adalah pengevaluasian terhadap pelaksanaan pada Proyek Peningkatan Jalan Alue Raya Line Pipa dengan nilai kontrak Rp. 2.978.000.000,- yang bersumber dana dari Pemerintah Kota Lhokseumawe dengan lebar badan jalan 5 meter, bahu 1 meter

Penilaian Pengendalian Biaya Dan Waktu Pada Proyek Peningkatan Jalan 
dan panjang jalan $1.057 \mathrm{~m}$ dengan waktu penyelesaian 120 hari kalender. Berdasarkan latar belakang di atas, maka rumusan masalah yang diteliti adalah apakah biaya penyelesaian pada proyek peningkatan Jalan Alue Raya-Line Pipa sesuai dengan biaya yang direncanakan atau mengalami kerugian, dan bagaimana memprediksikan atau memperkirakan waktu dan biaya penyelesaian perkerjaan proyek dan biaya penyelesaian proyek hingga proyek tersebut selesai tepat pada waktunya.

Menurut Husen (2010), pengkuran kemajuan aktual pekerjaan yang sudah dilakukan dapat dipakai sebagai data input dalam pengendalian proyek. Caranya dengan menghitung volume masing-masing kegiatan, lalu dibuatkan bobotnya dalam persentase komulatif biaya dalam bentuk kurva S. Kurva S juga didapat dari bobot komulatif pekerjaan sebagai persentase dari biaya per item pekerjaan dibagi dengan total anggaran proyek, dengan data yang ada pada format laporan pengendalian. Untuk mempermudah pengendalian proyek, pengelolaan proyek seharusnya mempunyai acuan sebagai sasaran dan tujuan pengendalian, oleh karena itu, indikator-indikator tujuan akhir pencapaian proyek haruslah ditampilkan dan dijadikan pegangan selama pelaksanaan proyek. Indikatorindikator yang biasanya menjadi sasaran pencapaian tujuan akhir proyek adalah kinerja biaya, mutu, dan waktu.

Untuk memantau keuangan proyek diperlukan indikator arus kas proyek yang menunjukkan rencana dan aktual penggunaan biaya dalam periode waktu proyek, seperti diperlihatkan pada Gambar 1.
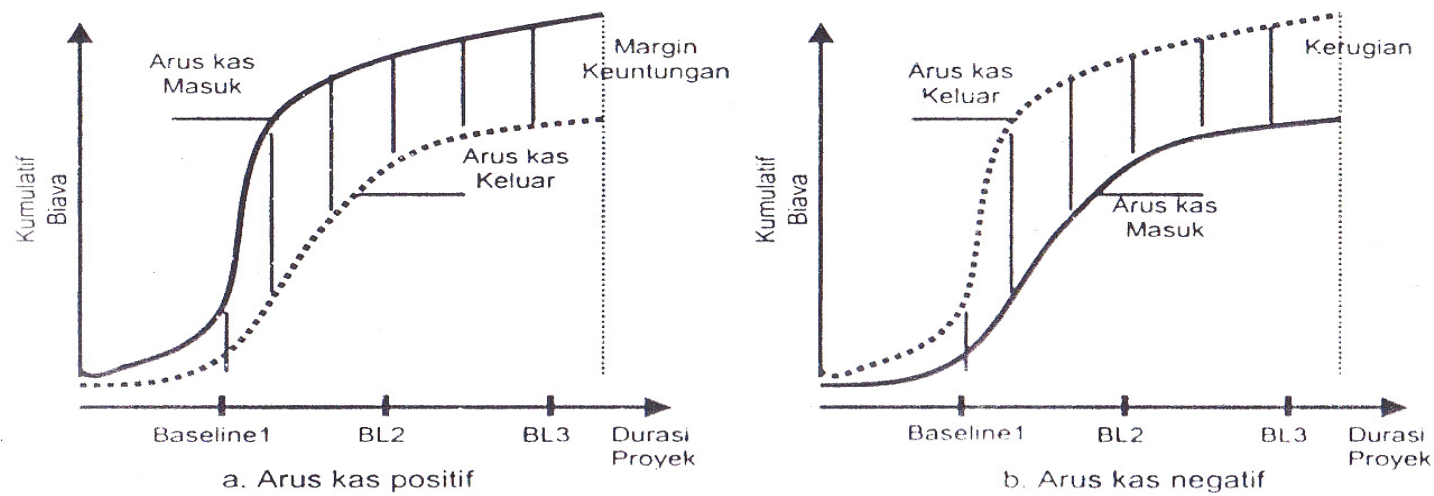

Gambar 1 Kurva S arus kas aktual

Sumber: Husen (2010)

Pada Gambar 1 ditunjukkan 2 kondisi aktual arus kas proyek di mana pada keadaan Gambar 1.a dengan arus kas positif, di mana posisi proyek mengalami keuntungan, sedangkan Gambar 1.b dengan arus kas negatif di mana posisi proyek mengalami kerugian. Untuk mendapatkan kurva seperti Gambar 1 dibuatkan sumbu y yang menunjukan biaya komulatif di-plot sepanjang durasi proyek sehingga membentuk kurva S. Sedangkan untuk memantau terhadap progres arus kas, dibuatkan monitoring baseline setiap periodik pembayaran termin atau disesuaikan dengan kondisi yang khusus. 


\section{Metode Penelitian}

Menurut Soeharto (1997), konsep nilai hasil (earned value) adalah konsep menghitung besarnya biaya yang menurut anggaran sesuai dengan pekerjaan yang telah diselesaikan atau dilaksanakan. Bila ditinjau dari jumlah pekerjaan yang selesai maka berarti konsep ini mengukur besarnya unit pekerjaan yang telah diselesaikan, pada suatu waktu bila dinilai berdasarkan jumlah anggaran yang disediakan untuk pekerjaan tersebut. Nilai hasil adalah biaya yang dianggarkan dari pekerjaan yang telah diselesaikan. Untuk menghitung nilai hasil dipakai rumus sebagai berikut:

$$
\text { Nilai hasil }=(\% \text { Penyelesaian }) x(\text { Anggaran Aktual })
$$

Menurut Iman Soeharto (1997), dalam konsep nilai hasil menggunakan 3 (tiga) indikator/parameter untuk menganalisis pencapaian pekerjaan dan membuat perkiraan pencapaian sasaran, yaitu:

1. BCWS (Budgeted Cost Work Schedule) adalah nilai anggaran untuk suatu paket pekerjaan yang dipadukan dari biaya, jadwal dan lingkup kerja dengan jadwal pelaksanaannya;

$$
B C W S=(\text { Total anggaran rencana }) x(\% \text { Penyelesaian rencana })
$$

2. BCWP (Budgeted Cost Work Performed) adalah nilai hasil dari sudut pandang nilai pekerjaan yang telah diselesaikan terhadap anggaran yang disediakan untuk melaksanakan pekerjaan tersebut;

$$
B C W P=(\text { Total anggaran rencana }) x(\% \text { Penyelesaian realisasi })
$$

3. ACWP (Actual Cost Work Permormed) adalah jumlah aktual dari pengeluaran atau dana yang digunakan untuk melaksanakan pekerjaan pada kurun waktu tertentu;

$$
A C W P=\% \text { Penyelesaian realisasi) }
$$

Dengan menggunakan 3 indikator di atas, dapat dihitung berbagai faktor yang menunjukkan kemajuan dan kinerja pelaksanaan proyek seperti:

1. Cost Varian (CV) adalah selisih antara nilai yang diperoleh setelah menyelesaikan paket-paket pekerjaan dengan biaya aktual yang terjadi selama pelaksanaan proyek. Rumus untuk menghitung variasi biaya adalah:

$$
C V=B C W P-A C W P
$$

2. Schedule Varian (SV) adalah selisih antara nilai yang diperoleh setelah menyelesaikan paket-paket pekerjaan dengan nilai anggaran umtuk suatu paket pekerjaan. Rumus untuk menghitung varian jadwal adalah: 


$$
S V=B C W P-B C W S
$$

3. Indeks Kinerja jadwal (SPI)

Schedule Performance Indeks (SPI) adalah perbandingan antara nilai hasil dengan pekerjaan yang direncanakan. Schedule Performance Indeks (SPI) dapat dihitung dengan menggunakan rumus:

$$
S P I=\frac{B C W P}{B C W S}
$$

4. Cost Performance Indeks (CPI)

Cost Performance Indeks (CPI) adalah perbandingan antara nilai hasil dengan biaya yang sudah direalisasikan. Indeks Kinerja Biaya (CPI) dapat dihitung menggunakan rumus sebagai berikut:

$$
C P I=\frac{B C W P}{A C W P}
$$

Dari parameter-parameter diatas maka dapat diprediksi total biaya pelaksanaan pada akhir proyek (EAC) dengan menggunakan rumus:

$$
E A C=\frac{B A C-B C W P}{C P I \times S P I}+A C W P
$$

Maka perkiraan varian biaya (VAC) antara biaya pelaksanaan dan anggaran menggunakan rumus sebagai berikut:

$$
V A C=B A C-E A C
$$

\section{Keterangan:}

$V A C=$ Selisih anggaran antara rencana dan pelaksanaan

$B A C=$ Nilai anggaran pekerjaan keseluruhan (tanpa pajak)

$E A C=$ Prediksi anggaran akhir pelaksanaan (tanpa pajak)

Menurut Husen (2009), dengan menghitung indeks-indeks seperti diatas akan terlihat bahwa proyek akan terlambat atau lebih cepat dan biaya yang harus dikeluarkan akan lebih atau kurang dari yang dianggarkan. Maka kemajuan proyek untuk waktu yang akan datang perlu diramalkan dengan cara berikut:

1. Estimated Completion Date (Perkiraan penyelesaian proyek)

$$
E C D=\frac{\text { Sisa waktu }}{\text { SPI }}+\text { Waktu terpakai }
$$




$$
\text { Prosentase keterlamba } \tan / \text { Percepa } \tan =\frac{100 \%-E C D}{\text { Jadwal rencana } x 100 \%}
$$

2. Estimated At Completion (Perkiraan Biaya Penyelesaian Proyek)

$$
E A C=\frac{\text { Sisa anggaran }}{C P I+A C W P}
$$

di mana:

Sisa anggaran $=$ Total biaya - BCWP

Persentase Biaya Penambahan/Penurunan Biaya Aktual terhadap Anggaran Biaya menjadi:

$$
P B P / P B A A=\frac{100 \%-E A C}{\text { Totalbiaya } x 100 \%}
$$

3. Earned Value (Nilai Hasil) sama dengan $\mathrm{BCWP}^{\mathrm{n}}$ (Biaya penyelesaian volume pekerjaan pada priode tertentu).

Dari ketiga hal tersebut indikator yang dapat dihitung pada Monitoring Baselline yang telah ditentukan, sehingga nilai-nilai yang didapat menunjukkan progress proyek yang pada periode tersebut dan progress proyek dari segi biaya dan waktu untuk penyelesaian pada masa yang akan datang.

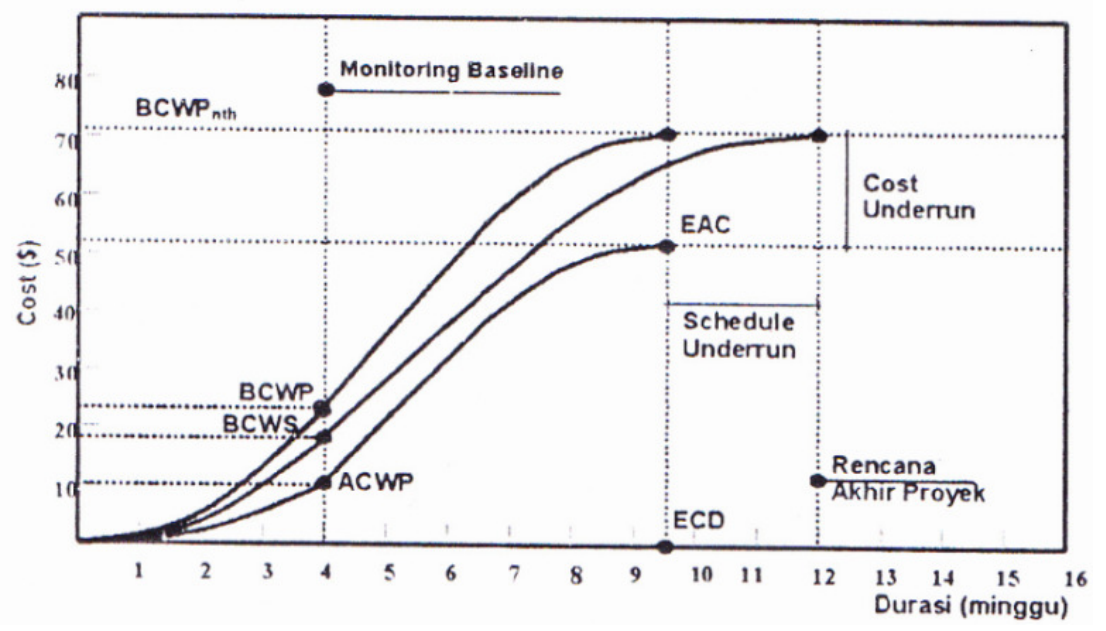

Gambar 2 Grafik kinerja biaya dan waktu

Sumber: Husen (2010). 
Pada metode ini tahap yang pertama adalah tinjauan pustaka yang diambil dari buku-buku dan bahan yang ada di $e$-book yang berhubungan dengan pengendalian biaya dan waktu pelaksanaan proyek. Metode earned value (nilai hasil) adalah konsep menghitung besarnya biaya yang menurut anggaran sesuai dengan perkerjaan yang telah dilaksanakan.

Kutipan buku Priyo (2009), "Metode earned value merupakan suatu konsep mengintergrasikan hubungan antar biaya dan waktu dan kinerja proyek dengan menentukan nilai uang untuk setiap bagiannya". Konsep dasar nilai hasil dapat digunakan untuk menganalisis kinerja dan membuat perkiraan pencapaian sasaran. Indikator yang digunakan dalam analisa biaya adalah ACWP, BCWP, BCWS, CV dan SV serta perkiraan penyelesaian proyek (ECD) dan perkiraan biaya penyelesaian proyek (EAD).

\section{Hasil dan Pembahasan}

Studi kasus ini dilakukan pada proyek Peningkatan Jalan Alue Raya - Line Pipa dan memiliki nilai kontrak Rp. 2.978.000.000,- yang bersumber dana dari Pemerintah Kota Lhokseumawe. Adapun hasil dari perhitungan BCWS, BCWP dan ACWP dapat dilihat pada Tabel 1.

Tabel 1 Nilai BCWP, BCWS dan ACWP

\begin{tabular}{|c|c|c|c|}
\hline Minggu & BCWP & BCWS & ACWP \\
\hline $\mathrm{Ke}-1$ & $\operatorname{Rp} 13,864,704.61$ & $\mathrm{Rp} \quad 1,600,728.13$ & $\operatorname{Rp} 10,816,327.02$ \\
\hline $\mathrm{Ke}-2$ & Rp $115,434,420.13$ & Rp $37,509,154.92$ & Rp 93,694,396.27 \\
\hline $\mathrm{Ke}-3$ & Rp 154,464,059.96 & Rp 204,364,587.82 & Rp 136,944,200.55 \\
\hline $\mathrm{Ke}-4$ & Rp 864,310,464.06 & $\operatorname{Rp} \quad 393,436,638.08$ & $\operatorname{Rp} 591,235,630.69$ \\
\hline
\end{tabular}

\subsection{Analisis Varian Terpadu}

Adapun hasil dari perhitungan Varians Terpadu yang meliputi Cost Varians, Schedulle Varians, Cost Performance Indeks, dan Schedulle Performance Indeks adalah sebagai berikut:

Tabel 2 Nilai Varians Terpadu

\begin{tabular}{cccccc}
\hline Minggu & BCWP & BCWS & ACWP & CV & SV \\
\hline 1 & 2 & 3 & 4 & $5=2-4$ & $6=2-3$ \\
\hline Ke-1 & Rp.13,864,704.61 & Rp.1,600,728.13 & Rp.10,816,327.02 & Rp.3,048,377.59 & Rp.12,263,976.48 \\
\hline Ke-2 & Rp.115,434,420.13 & Rp.37,509,154.92 & Rp.93,694,396.27 & Rp.21,740,023.86 & Rp.77,925,265.21 \\
\hline Ke-3 & Rp.154,464,059.96 & Rp.204,364,587.82 & Rp.136,944,200.55 & Rp.17,519,859.41 & Rp.(49,900,527.85) \\
\hline Ke-4 & Rp.864,310,464.06 & Rp.393,436,638.08 & Rp.591,235,630.69 & Rp.273,074,833.38 & Rp.470,873,825.98 \\
\hline
\end{tabular}

Penilaian Pengendalian Biaya Dan Waktu Pada Proyek Peningkatan Jalan Menggunakan Metode Earned Value - Bakhtiar. A 
Tabel 3 Nilai Indeks Kinerja Proyek

\begin{tabular}{cccccc}
\hline Minggu & BCWP & BCWS & ACWP & CPI & SPI \\
\hline 1 & 2 & 3 & 4 & $5=2 / 4$ & $6=2 / 3$ \\
\hline Ke-1 & Rp.13,864,704.61 & Rp.1,600,728.13 & Rp.10,816,327.02 & 1.28 & 8.66 \\
\hline Ke-2 & Rp.115,434,420.13 & Rp.37,509,154.92 & Rp.93,694,396.27 & 1.23 & 3.08 \\
\hline Ke-3 & Rp.154,464,059.96 & Rp.204,364,587.82 & Rp.136,944,200.55 & 1.13 & 0.76 \\
\hline Ke-4 & Rp.864,310,464.06 & Rp.393,436,638.08 & Rp.591,235,630.69 & 1.46 & 2.20 \\
\hline
\end{tabular}

\subsection{Indek Produktifitas Kinerja Biaya dan Waktu}

Indek produktivitas kinerja biaya dan waktu dihitung berdasarkan persamaan 8 dielaborasi sebagai berikut:

a. Perhitungan Estimated Completion Date (ECD) sampai dengan minggu ke-4 dilakukan dengan menghitung sisa waktu dibagi SPI dan ditambah dengan waktu terpakai, maka ECD menjadi sebesar 9,4. Persentase keterlambatan/ percepatan sebesar $0,53 \%$.

b. Perhitungan Estimated at Completion (EAC) sampai dengan minggu ke-4 dilakukan dengan menghitung total biaya dikurang BCWP kemudian dibagi SPI dan ditambah dengan ACWP, maka diperoleh EAC sebesar Rp $2,037,182,494.70$. Persentase penurunan biaya aktual sebesar $95 \%$.

\subsection{Grafik Kinerja Biaya dan Waktu}

Prediksi biaya dan waktu pada proyek peningkatan jalan Alue Raya-Line Pipa menunjukkan rencana dan aktual penggunaan biaya dalam periode waktu proyek, seperti di bawah ini.

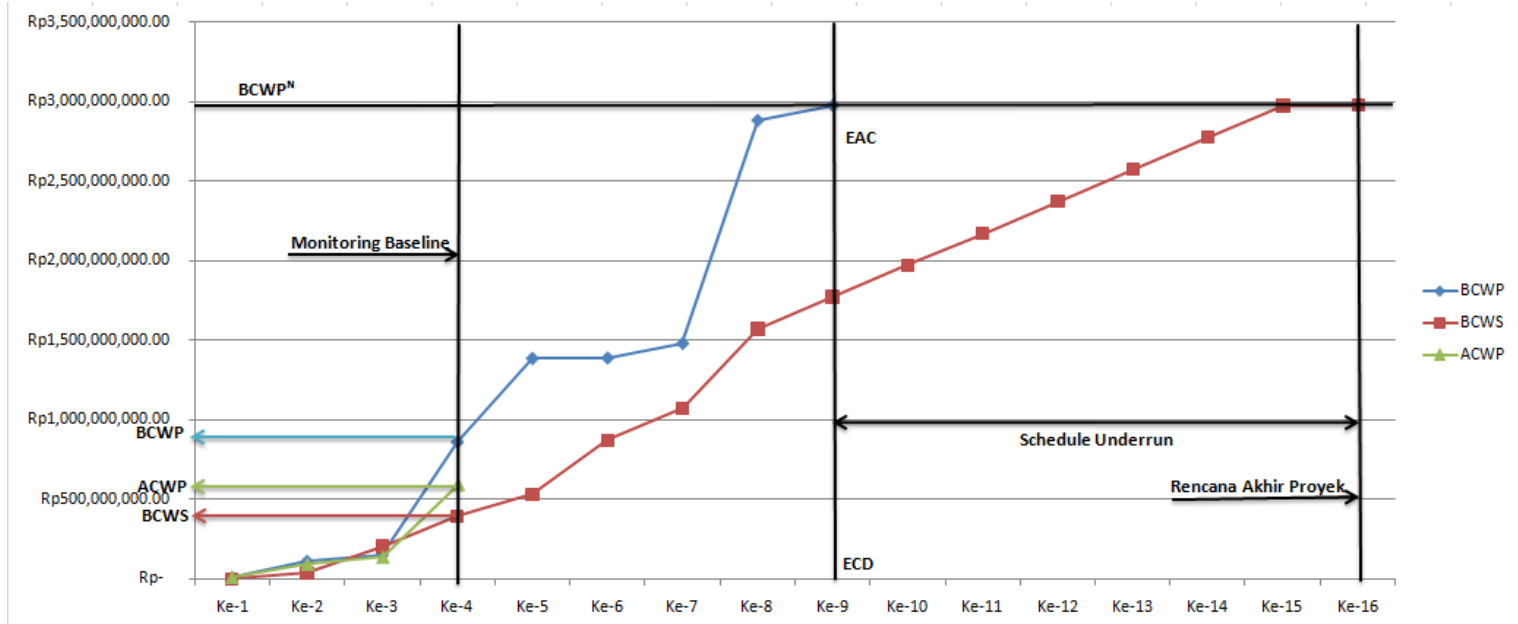

Gambar 3 Grafik prediksi Waktu dan Biaya Penyelesaian Proyek s.d akhir minggu ke-16 


\section{Kesimpulan dan Saran}

\subsection{Kesimpulan} berikut:

Dari penelitian yang sudah dilaksanakan dapat diambil kesimpulan sebagai

1. Nilai biaya penyelesaian pelaksanaan akhir proyek didapat nilai hasil yang dihitung sampai minggu ke-4 adalah BCWP (Budgeted Cost Work Performed) sebesar Rp. 864,310,464.06, BCWS (Budgeted Cost Work Schedulle) sebesar Rp. 393,436,638.08, dan besaran ACWP (Actual Cost Work Performed) sebesar Rp. 591,235,630.69.

2. Indikator cost varian (CV) dihitung sampai minggu ke-4 yang bernilai positif yaitu Rp. 273,074,833.38 atau dari nilai indeks kinerja biaya $(\mathrm{CPI})=1,46>1$, Indikator schedule varian (SV) yang bernilai positif yaitu Rp. 470,873,825.98 atau dari nilai indeks kinerja biaya $(\mathrm{SPI})=2,20>1$, sehingga dengan $\mathrm{SV}=(+)$ dan $\mathrm{CV}=(+)$ menunjukan pekerjaan terlaksana lebih cepat dari pada jadwal dengan biaya lebih rendah dari pada anggaran, dengan SPI $>1$ menunjukan bahwa pekerjaan mengalami percepatan dan CPI $>1$ maka menunjukkan kinerja biaya yang baik dan tidak terjadi pemborosan.

3. Indikator produktivitas kinerja biaya dan waktu, dengan ECD sebesar 9,45 minggu lebih cepat dari waktu pekerjaan rencana selama yaitu 16 minggu dan EAC sebesar Rp. 2,037,182,494.70.- sehingga berkurang dari anggaran rencana sebesar Rp. 2,978,098,842.48.

\subsection{Saran}

Saran-saran yang dapat diberikan berdasarkan hasil penelitian ini adalah bahwa untuk mempercepat waktu pekerjaan dan efisiensi biaya pelaksanaan dapat digunakan penilaian pengendalian biaya dan waktu dengan metode earned value.

\section{Daftar Kepustakaan}

Husen, Abrar, 2010, Manajemen Proyek. Penerbit Andi, Yogyakarta.

Kementrian Pekerjaan Umum dan Perumahan Rakyat, 2016, Tentang Analisa Harga Satuan Pekerjaan Bina Marga 2016.

Priyo, Mahdiyo, 2009, Metode earned value Pada Jasa Konstruksi, Penerbit Lembaga Penelitian dan Pengembangan Pendidikan Universitas Muhammadiyah, Yogyakarta.

Soeharto Iman, 1999, Manajemen Proyek, Dari Konseptual sampai Operasional. Penerbit Erlangga, Jakarta. 